\title{
Effect of extreme severe heat stress on respiratory rate in unshorn and shorn Australian Merino rams from Northern Patagonia
}

\section{Efeito do estresse por calor extremamente intenso sobre a taxa respiratória de carneiros Merino Australiano com lã e tosquiados da Patagônia Norte, Argentina}

\author{
María Fernanda LÓPEZ ARMENGOL ${ }^{1,2}$; Romina Paola FREUND; Gustavo Néstor GIMÉNEZ ${ }^{2,3}$; Natalia RUBIO \\ ${ }^{1}$ Universidad Nacional del Comahue, Facultad de Ciencias Agrarias, Laboratorio de Teriogenología "Dr. Héctor H. Morello", \\ Cinco Saltos - Río Negro, Argentina \\ ${ }^{2}$ Consejo Nacional de Investigaciones Científicas y Técnicas (CONICET), Centro de Investigaciones en Toxicología Ambiental y \\ Agrobiotecnología del Comahue (CITAAC) - Neuquén, Argentina \\ ${ }^{3}$ Universidad Nacional del Comahue, Facultad de Economía y Administración, Departamento de Estadística - Neuquén, Argentina
}

\begin{abstract}
The aim of this study was to determine the effects of severe extreme thermal stress on the respiratory rate (panting) of unsheared and sheared rams in standing and lying position, and to analyse two temperature-humidity indices (THIs). Six mature Australian Merino rams from Northern Patagonia, three unshorn and three shorn, were subjected to 40 hours ( 8 hours each day for five days) of gradual increase in temperature from $25^{\circ} \mathrm{C}$ to $40^{\circ} \mathrm{C}$, guaranteeing $4 \mathrm{~h}$ daily at $40^{\circ} \mathrm{C}$ in a heat chamber. Respiratory rate $(\mathrm{RR})$ was registered continuously by counting flank movements, and the ambient air temperature and relative humidity were recorded every five minutes inside the heat chamber. From $1413 \mathrm{RR}$ measurements, descriptive and modelling analyses were performed. Panting as a response variable was distributed into five categories, and fixed effects such as THI, wool (unshorn/shorn), and position (standing/lying) were considered. No significant differences were observed between the panting score in the unshorn (standing or lying) and standing (unshorn or shorn) sheep, but significant differences were observed in shorn and lying rams. The explanations could be that heat production from muscle activity was lower and the transfer and heat lost by conduction to the floor was easier in the rams with shorter fleece (at least 0.7 inches long). However, in the unshorn rams, their wool acted as an insulator, both with air as well as the floor. Australian Merino rams from Northern Patagonia are heat tolerant to an environment between $31.5^{\circ} \mathrm{C}$ and $42^{\circ} \mathrm{C}$, and $32 \%$ to $48 \%$ humidity for 40 hours over five days. The rams were in the first phase of panting, and the normal rectal temperatures registered daily when leaving the heat chamber confirmed that regulation of body temperature was possible. The LPHSI's THI was adjusted to improve the analysis of the RR more than the National Research Council's THI.
\end{abstract}

Keywords: Australian Merino rams. Heat stress. Respiratory rate. Unshorn / shorn. Standing / lying down.

\section{Resumo}

O objetivo deste estudo foi determinar o efeito do estresse térmico extremamente severo sobre a frequência respiratória (ofego) em carneiros com lã e tosquiados, em pé ou deitados, e analisar dois índices de temperatura e umidade (ITU). Seis carneiros Merino Australiano da Patagônia Norte, três com lã e três tosquiados, foram expostos durante 40 horas a aumento gradual de temperatura de 25 a $40^{\circ} \mathrm{C}$ (oito horas durante cinco dias), garantindo quatro horas diárias a $40^{\circ} \mathrm{C}$ em uma câmara de calor. A frequência respiratória foi registrada continuamente mediante a contagem dos movimentos do flanco. A temperatura e a umidade relativa ambiente foram registradas a cada cinco minutos dentro da câmara. A partir de 1.413 frequências respiratórias registradas, uma análise descritiva foi realizada e um modelo calculado. A variável de resposta do ofego foi dividida em cinco categorias e os efeitos fixos considerados foram: ITU, lã (com lã ou tosquiado) e posição (em pé ou deitado). Não se observaram diferenças significativas nas frequências de ofego nos carneiros com lã (em pé ou deitados) nem entre os carneiros em pé (com lã e tosquiados), mas foram observadas diferenças significativas nos carneiros tosquiados deitados. Essas diferenças podem ser atribuídas à perda de calor com o solo, facilitada nos carneiros com mecha mais curta (pelo menos $1,8 \mathrm{~cm}$ ), e à baixa produção de calor de atividade de músculo. Nos carneiros lanados, a lã atua como isolante tanto com o ar quanto com o solo. Os carneiros Merino Australianos do Norte da Patagônia foram adaptados a temperaturas ambiente entre 31,5 e $42^{\circ} \mathrm{C}$ e 32 e $48 \%$ de umidade durante 40 horas em cinco dias. Os carneiros permaneceram na primeira fase do ofego e as temperaturas retais diárias, que se registraram ao deixar a câmara de calor, permaneceram dentro da normalidade, o que demonstra que eles puderam regular a temperatura corporal. 
Além disso, foram analisados comparativamente os ajustes à frequência respiratória dos ITUs: LPHSI e National Research Council.

Palavras-chave: Carneiros Merino Australiano. Estresse térmico. Frequência respiratória. Com lã e tosquiados. Em pé ou deitados.

Correspondence to:

María Fernanda López Armengol

Universidad Nacional del Comahue, Facultad de Ciencias

Agrarias, Laboratorio de Teriogenología “Dr. Héctor H.

Morello"

Ruta $151 \mathrm{~km} 12$

CP 8303, Cinco Saltos, Río Negro, Argentina

E-mail: m.lopezarmengol@conicet.gov.ar

Received: 16/12/2015

Approved: 11/01/2017

\section{Introduction}

In temperate regions, mean temperatures are expected to increase due to climate changes. This increased temperature could have negative effects on agriculture, biodiversity, the energy sector, hydrology, and human and animal health (SOLYMOSI et al., 2010). Different models predict changes in the climate of the world, with an increase of the concentration of atmospheric $\mathrm{CO}_{2}$, increases in temperature, and changes in the distribution of rainfall. Global media estimate the increase in surface temperature ranges from $1.5^{\circ} \mathrm{C}$ to $4.5^{\circ} \mathrm{C}$ (ARIAS et al., 2008).

Climate is one of the most important factors in animal adaptation to its surrounding environment (KARAMAN et al., 2013). The variation in climatic variables such as temperature, humidity, air movement, photoperiod, and solar radiation may impose stress on the productive and reproductive performance traits of sheep. Additionally, the effect of environmental temperature is aggravated in the presence of high relative humidity (CURTIS, 1983; HAFEZ, 1987).

Sheep have been used in a variety of climates with different micro-environmental conditions and food availability, emphasizing their high capacity for adaptation in environments where cold or temperate, arid or dry and tropical and humid climates prevail. Despite the physiological and biological versatility of sheep to tolerate environmental conditions, the heat stress of micro-environmental conditions impact negatively on life processes and functions related to animal production (growth, reproduction, behaviour, animal activity, gestation, lactation, and health) (ARAÚZ, 2009). Consequently, it should be noted that sheep's production demands physiological assessments of such micro-environmental conditions in order to establish strategies specifically aimed at reducing the degree of heat stress (ARAÚZ, 2009).

Respiratory rate is the major evaporative heat loss mechanism of sheep exposed to high temperatures, and the total heat loss from the respiratory tract accounts for approximately $65 \%$ of their total heat dissipation (HALES; BROWN, 1974; THWAITES, 1985; CAULFIELD et al., 2014). Sweating is less important to sheep as a means of evaporative heat loss at high temperature. The normal resting respiratory rate for sheep is between 20 and 38 breaths/minute (bpm). As a sheep responds to increased environmental heat, it will have an increased respiratory rate and altered depth of respiration as a response known as panting. In sheep, there are two phases of panting: the first phase consists of shallow movements that draw the air backwards and forwards on the moist surface of the naso-buccal region. Occasionally the animal performs a deep breathing that responds to the need for the exchange of gases (HALES; WEBSTER, 1967; STOCKMAN, 2006).

The rate of respiration and breathlessness scale are affected by environmental temperature, humidity, genotype, body condition, medical history, and temperament of the animals (BROWN-BRANDL et al., 2005; BROWN-BRANDL et al., 2006). Merino and Dorset sheep reached an average respiratory rate of 294 and $272 \mathrm{bpm}$, respectively, after one hour of exposure at $28^{\circ} \mathrm{C}$ (HALES; WEBSTER, 1967). Beatty et al. (2008) reported that respiration rate in shorn Merino wethers increased from $40 \mathrm{bpm}$ to $119 \mathrm{bpm}$ when the temperature increased from $25^{\circ} \mathrm{C}$ to $33^{\circ} \mathrm{C}$. Alhidary et al. (2012) demonstrates that the exposure of 9-mo-old Australian Merino wethers to increased environmental temperature from $28^{\circ} \mathrm{C}$ to $38^{\circ} \mathrm{C}$ for a 7 -day period resulted in increase of $0.8^{\circ} \mathrm{C}$ in rectal temperature and in respiration rate by 66 breaths/minute. 
In the live export and feedlot industry, the panting score has been used to measure animal performance regarding heat tolerance because it appears to be the most accessible and the easiest method to evaluate the impact of heat stress (MEAT \& LIVESTOCK AUSTRALIA, 2001; MCCARTHY, 2005; STOCKMAN, 2006; BRYANT et al. 2010; CAULFIELD et al., 2014). At the start of the fast, shallow breathing or panting phase is a good indicator of the onset of thermal stress in species that rely heavily on cooling respiratory (MONTY JUNIOR et al., 1991; STOCKMAN, 2006). In more recent studies, Brown-Brandl et al. (2005) concluded that the rate of respiration is a more appropriate indicator to monitor stress by heat in cattle.

Silanikove (2000) attempted to quantify the severity of heat stress in livestock according to panting rate as low, 40 - 60; medium high, 60 - 80; high, 80 - 120 bpm; and severe heat stress, above $150 \mathrm{bpm}$ in cattle, and above $200 \mathrm{bpm}$ in sheep.

A temperature-humidity index (THI) is a single value representing the combined effects of air temperature and humidity, commonly applied to estimate the level of thermal stress in livestock industries. This index has been developed as a weather safety index to monitor and reduce heat-stress-related losses (BOHMANOVA et al., 2007). Bohmanova et al. (2007) concluded that THIs differ in their ability to detect heat stress depending on the weather. For hot and semiarid climates, as in Northern Patagonia, the National Research Council's (1971) THI would be the best. Marai et al. (2009) used the LPHSI (1990) index with Egyptian Suffolk rams, and the values obtained indicate the following scores: $<22.2=$ absence of heat stress; 22.2 to $<23.3=$ moderate heat stress; 23.3 to $<25.6=$ severe heat stress; 25.6 and more $=$ extreme severe heat stress.

Research results regarding the effects of shearing on respiratory frequency are controversial. Dutt and Hamm (1957) concluded that, for Southdown rams, shearing before exposure in a heat chamber $\left(32.2^{\circ} \mathrm{C}\right.$ and $60 \%$ to $65 \%$ humidity) reduced heat stress as measured by changes in body temperature, pulse rate, and respiratory rate compared with the responses of unshorn rams under a similar treatment. The respiratory rates observed were 134 breaths/minute in shorn and 178 breaths/minute in unshorn rams. In hot, dry heat without solar radiation, Hofman and Riegle (1977) conclude that there was no difference between shorn and unshorn sheep in terms of respiratory frequency or blood gas values. However, Stockman (2006) states that unshorn sheep experienced a downshift in the set point of thermoregulation that resulted in lower threshold for panting. Beatty et al. (2008) studied the effect of fleece on core and rumen temperatures and on respiratory rate, concluding that during all environmental conditions to which the sheep were exposed, the presence of fleece was associated with higher core and rumen temperatures, and also higher respiratory rates.

However, none of the authors mention the posture of the rams, which could affect the spending muscle energy, and transfer of the heat by conduction. When the sheep is standing, it spends more muscle energy and therefore produces more heat in contrast to the resting position (LOBLEY, 1990). Conduction of heat takes place between physical bodies that are in contact with each other, whether they are solid, liquid or gases, and it always occurs from a region of higher temperature to one of lower temperature (SCHMIDT-NIELSEN, 1997). Conductive heat transfer in the air occurs when the animal is standing, and direct conductive heat exchange occurs when the animal is in contact with solid surfaces, such as when it is lying down.

The aim of this study is to determine the effects of severe extreme thermal stress on respiratory rate and gas exchange of unshorn and shorn Australian Merino rams from Northern Patagonia in standing or lying position. Another aim is to analyse two temperature-humidity indices in order to identify the one most suitable when dealing with physiological variables such as panting in rams exposed to heat stress in hot and arid climate.

\section{Materials and Methods}

\section{Experimental location and animals}

The experiment was conducted during the summer season from 14 to 18 February 2011, at Facultad de Ciencias Agrarias (FCA), Universidad Nacional del Comahue, near Cinco Saltos (Province of Río Negro, Argentina). The region has an arid environment with an annual average rainfall of $186.24 \mathrm{~mm}$ (range $=90.7 \mathrm{~mm}-357.4 \mathrm{~mm}$ ) and annual average temperatures of $14.91^{\circ} \mathrm{C}$ (range $=1.4^{\circ} \mathrm{C}$ to $33.7^{\circ} \mathrm{C}$; 2001-2010 data). Climatologic information regarding this location during the course of the study is summarized in table 1 . 
Table 1 - Climatologic information of experiment location. Mean day temperature, relative humidity, Temperature-Humidity Index (THI), and rainfall from December 21 st 2010 to March 21 $1^{\text {st }}, 2011$ - Argentina

\begin{tabular}{|c|c|c|c|c|c|c|c|c|c|c|}
\hline & \multicolumn{2}{|c|}{$\begin{array}{c}\text { Temperature } \\
\left({ }^{\circ} \mathrm{C}\right)\end{array}$} & \multicolumn{2}{|c|}{$\begin{array}{c}\text { Relative humidity } \\
\text { (\%) }\end{array}$} & \multicolumn{2}{|c|}{ THI 1} & \multicolumn{2}{|c|}{ THI 2} & \multicolumn{2}{|c|}{ Rainfall (mm) } \\
\hline & Mean & \pm SD & Mean & \pm SD & Mean & \pm SD & Mean & \pm SD & Mean & \pm SD \\
\hline 21 to 31 December 2010 & 23.4 & 5.3 & 51.1 & 19.2 & 21.8 & 4.2 & 69.1 & 6.0 & 7.7 & 0.2 \\
\hline 1 to 31 January 2011 & 22.2 & 6.4 & 49.2 & 20.0 & 20.7 & 5.1 & 67.2 & 7.4 & 5.7 & 1.3 \\
\hline 1 to 28 February 2011 & 21.7 & 6.8 & 49.4 & 19.8 & 20.3 & 5.3 & 66.6 & 7.8 & 19.0 & 5.8 \\
\hline 1 to 21 March 2011 & 18.6 & 7.7 & 51.4 & 20.4 & 17.6 & 6.3 & 62.3 & 9.5 & 5.0 & 2.4 \\
\hline
\end{tabular}

Abbreviation: SD, standard deviation

In total, six healthy mature Australian Merino rams were randomly selected from a sheep farm according to their physical condition (corporal condition $=2.5$ to 3.5). Three unshorn (fleece length 4.3 inches long = Us) and three shorn (fleece length 0.7 inches long $=S$ ) sheep, aged $31 / 2$ to 4 years, with live body weight ranging from 52 to $59 \mathrm{Kg}$ were selected. The rams were previously acclimatized for three months. The shearing was applied to the whole body before the adaptation period, and the remaining fleece was 0.2 inches long after shearing and 0.7 inches long at the beginning of the heat chamber experiment. Food was offered once a day at $09.00 \mathrm{~h}(1,350 \mathrm{~g}$ of Lucerne dry matter and oat energy supplement). Water was available ad libitum. The whole experiment was performed considering animal welfare conditions in accordance with the statements at FCA, Universidad Nacional del Comahue.

\section{Experimental design}

The rams under the heat chamber conditions were exposed to heat stress for eight hours (from 09:00 to 17:00) over five days (14 to 18 February 2011) and exposed to natural photoperiods throughout the experiment followed by housing in open pens. Three weeks before the experiment (24 January 2011), the six rams were transferred to a place with two spaces: one open space, which was connected to another, closed space (heat chamber), where they could continuously circulate freely in environmental temperature. During the four days of treatment, they entered the heat chamber at 9:00, were fed and subjected to heat; at 17:00, they went into the open space, where they spent the night. During the eight hours the rams remained in the heat chamber, they were subjected to a gradual increase in temperature from $25^{\circ} \mathrm{C}$ to $40^{\circ} \mathrm{C}$, guaranteeing four hours daily at $40^{\circ} \mathrm{C}$. Ambient air temperature (nearest $0.01^{\circ} \mathrm{C}$ ) and relative humidity (RH \%, nearest 1\%) were recorded in the heat chamber every five minutes using a $\mathrm{HOBO}$ Micro Station Data Logger (USA).

Details of the microclimatic heat chamber conditions over five days (from 09.00 to 17.00 hours, totalling 40 hours) of the experiment are provided in table 2.

Individual rectal temperature (RT) was measured as a valuable physiological characteristic of regulation of body temperature as a heat response by means of a digital thermometer $\left(\mathrm{ST}-9285 / \mathrm{B}\right.$, range $=-50^{\circ} \mathrm{C}$ to $150^{\circ} \mathrm{C}$, resolution: $0.1^{\circ} \mathrm{C}$ ) twice, once upon entering and again upon leaving the heat chamber.

Table 2 - Microclimatic heat chamber conditions over 5 days of the experiment (from 09:00 to 17:00 hours, total = 40 hours). Mean temperature, relative humidity, and Temperature-Humidity Index (THI) - Argentina

\begin{tabular}{|c|c|c|c|c|c|c|c|c|}
\hline & \multicolumn{2}{|c|}{ Temperature $\left({ }^{\circ} \mathrm{C}\right)$} & \multicolumn{2}{|c|}{ Relative humidity (\%) } & \multicolumn{2}{|c|}{ THI 1} & \multicolumn{2}{|c|}{ THI 2} \\
\hline & Mean & \pm SD & Mean & \pm SD & Mean & \pm SD & Mean & \pm SD \\
\hline Feb-14 & 38.2 & 2.8 & 42.4 & 3.2 & 33.9 & 2.3 & 87.1 & 3.4 \\
\hline Feb-15 & 38.6 & 3.7 & 38.0 & 3.6 & 33.9 & 2.9 & 86.5 & 4.0 \\
\hline Feb-16 & 39.6 & 3.4 & 37.0 & 4.3 & 34.7 & 2.5 & 87.5 & 3.4 \\
\hline Feb-17 & 39.4 & 3.2 & 41.0 & 2.2 & 33.1 & 3.2 & 88.3 & 3.9 \\
\hline Feb-18 & 37.2 & 4.0 & 43.2 & 3.2 & 33.2 & 3.2 & 86.1 & 4.3 \\
\hline
\end{tabular}

Abbreviation: SD, standard deviation 


\section{Registration of respiratory rate}

Videos from 15 to 18 February were analysed using the VLC media player program in slow motion ( $=0.5$ speed $)$, counting the breaths taken in 12 seconds. Respiratory rate (RR) was registered in breaths per minute (bpm) continuously by counting flank movements (BIANCA, 1965) from the footage of the rams considering unshorn/ shorn and standing/lying down under the experimental conditions. We distinguished the typical panting ( $R R p)$ from an occasional deep breath, which meets the animal's need for gas exchange.

\section{Estimation of heat stress severity}

A means of estimating the severity of heat stress inside the heat chamber was proposed using both ambient temperature and relative humidity registered every five minutes, termed the temperature-humidity index (THI). The equations used were:

THI $1=\mathrm{Tdb}-\{(0.31-0.31 \mathrm{RH})(\mathrm{Tdb}-14.4)\}($ LPHSI, 1990; MARAI et al., 2001; MARAI et al., 2009)

THI $2=(1.8 \mathrm{Tdb}+32)-\{(0.55-0.55 \mathrm{RH})(1.8 \mathrm{Tdb}-26)\}$

National Research Council (1971)

where $\mathrm{Tdb}$ is the dry bulb temperature $\left({ }^{\circ} \mathrm{C}\right)$ and $\mathrm{RH}$ is the relative humidity $(\mathrm{RH} \%) / 100$. Marai et al. (2009) used THI 1 on Egyptian Suffolk rams, and the values obtained indicate the following scores: $<22.2=$ absence of heat stress; 22.2 to $<23.3=$ moderate heat stress; 23.3 to $<25.6=$ severe heat stress; 25.6 and more $=$ extreme severe heat stress. Each RR registered in the footage corresponded to its respective THI inside the heat chamber.

\section{Statistical analysis Comparing THI}

In order to analyse which THI provides a better explanation for the RRp, linear regression, determination $\left(\mathrm{r}^{2}\right)$, and correlation coefficients $(\mathrm{r})$ were calculated.

\section{Panting}

\section{Descriptive analysis}

Panting was analysed from a database that included $1413 \mathrm{RRp}$ in bpm: unshorn $=645$; shorn $=$ 768 ; standing $=1303$; lying down $=110$. An initial descriptive analysis was conducted including a bar graph to illustrate the frequency of panting in standing and lying rams.

\section{Modelling panting}

The significance of the differences between the rams' conditions was analysed using a model in which the response variable $R R p$ was divided in five categories: [40 - 60) bpm; [60 - 80) bpm; [80 - 120) bpm; [120 - 150) bpm and [150 - 190) bpm, where the first three categories agree with the ones proposed by Silanikove (2000) and the rest were established as a way of including the RR between 120 and $190 \mathrm{bpm}$.

Because the response variable $\mathrm{RRp}$ is an ordinal variable, a Cumulative-Logit was estimated, where the fixed effects were: THI 1; Wool (W = Us / S) and Position $(\mathrm{P}=\mathrm{St} / \mathrm{L})$. The subject effect "Ram" was estimated trough a Generalized Linear Mixed Model (GLMM) as follows:

$\operatorname{logit}\left[P\left(Y_{i t} \leq j / x\right]=\alpha_{j}+X^{\prime}{ }_{i t} \beta+Z^{\prime}{ }_{i t} b_{i}+e_{i t} \quad j_{=} 1, \ldots, J-1\right.$ where:

$\mathrm{Y}_{\mathrm{it}}$ denotes observation $t$ to subject $i$. RR with $j$ categories. $\mathrm{n}_{\mathrm{i}}$ is the number of repetitive measure in the time to subject $i$.

$\mathrm{X}_{\mathrm{it}}$ is the design matrix of order $\left(\mathrm{n}_{\mathrm{i}} \mathrm{x} p\right)$ that characterizes the systematic part of the design where $p$ is the number of fixed effects of the model.

$\beta$ is the parameter vector of the fixed effects of the model that complete the systematic part of the model.

$\mathrm{Z}_{\mathrm{it}}$ is the design matrix of order $\left(\mathrm{n}_{\mathrm{i}} \mathrm{x} q\right)$ that characterizes the random part of the model. It is the source of variation between subjects; $q$ is the number of random effects in the model.

$\mathrm{b}_{\mathrm{i}}$ is a vector $(q \times 1)$ of random effects.

$e_{i t}$ is a vector of random errors of variation within each subject due to the way in which the response variable in each subject was measured.

$\mathrm{b}_{\mathrm{i}}$ and $\mathrm{e}_{\mathrm{it}}$ are variation sources present in the model, between and within subjects, respectively.

We start from a GLMM, which takes into account the double and triple interactions as well as the main effects in order to achieve a simple model.

Subsequently, two models were compared using a likelihood test, one including the random effects (Ram) and the other without such effects.

To achieve a deeper analysis of the main effects, individual rams were analysed in each category, taking into account the four conditions: unshorn (Us), shorn (S), standing (St), and lying down (L), making the corresponding adjustment in the RRp.

The statistical analysis was performed with statistical language $\mathrm{R}$ version 3.0.2. The libraries used were: ordinal, lm4, and nlme (R CORE TEAM, 2015). 


\section{Results}

\section{Comparison of THIs}

The temperature and humidity varied through the experience between 31.5 and $42^{\circ} \mathrm{C}$ and 32 to $48 \%$, respectively. The THI 1 calculated through the experiment varied between 28.6 and 37.1; the THI 2 varied between 79.6 and 92.0 .

The determination coefficients applied to analyse the adjustment of THI to RR resulted in THI $1=0.27$ and THI $2=0.24$, which means that $27 \%$ of the variability of RR is explained by the variability of THI 1 , whereas in the case of THI 2 , the variability of RR is $24 \%$. The correlation coefficients resulted in THI $1=0.52$ and THI $2=0.49$. For that reason, it was decided to continue the analysis using THI 1.

\section{Panting}

\section{Descriptive analysis}

At all times, it was observed that the rams inside the heat chamber were in the first phase of panting, which involved mainly shallow movements that draw air backward and forwards, with an occasional deep breath. The second phase of panting, characterized by deeper, slower respirations with mouth open and tongue protruding was never observed in the rams. The rectal temperatures registered daily when leaving the heat chamber confirmed that the regulation of body temperature in rams was possible because they had the normal rectal temperature range in sheep $\left(38.3\right.$ to $\left.39.9^{\circ} \mathrm{C}\right)$.

Figure 1 illustrates the RRp in Us and S rams, standing (Figure 1.a) and lying down (Figure 1.b). It is important to note that when the rams were standing, the shorn rams presented low RRp (50 to $100 \mathrm{bpm}$ ) more frequently than the unshorn rams, while the unshorn presented high RRp more frequently than the shorn (140 to $180 \mathrm{bpm}$ ) (Figure 1.a). The same results were seen when the rams were lying down; the most frequent RRp of shorn rams was between 50 and $100 \mathrm{bpm}$, while in the unshorn rams, the most frequent RRp was between 110 and $140 \mathrm{bpm}$ (Figure 1.b).

Table 3 illustrates the RRp of standing and lying rams at different THI 1 . The significance of the difference observed between the rams' conditions was analysed by modelling.

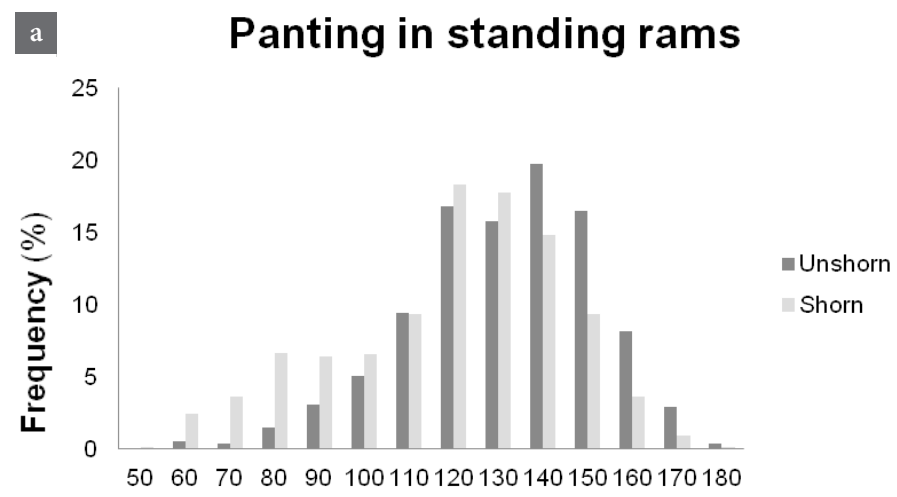

Respiratory Rate (breaths/minute)

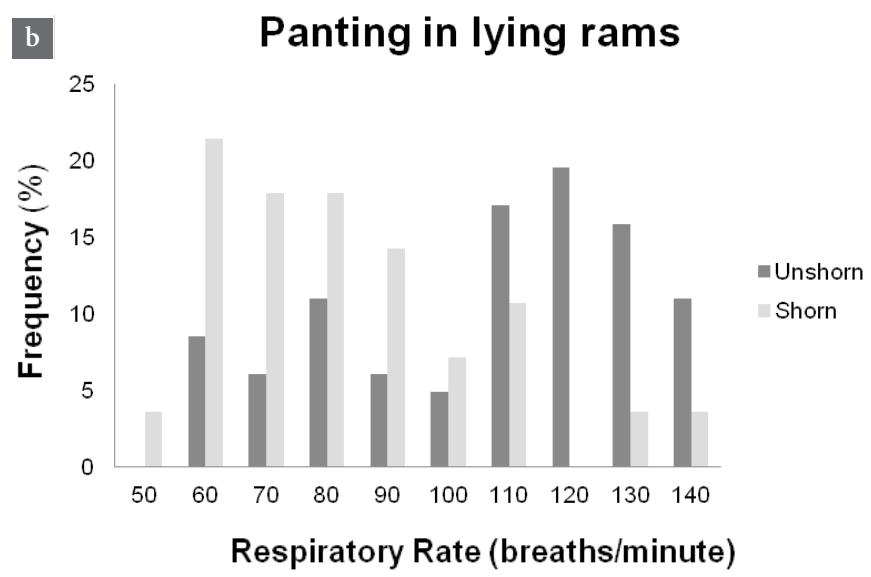

Figure 1 - Bar graph of the percentage of panting in standing and lying rams. a. Respiratory rate (breaths/minute) in standing unshorn and shorn rams. b. Respiratory rate (breaths/minute) in lying down unshorn and shorn rams 
Table 3 - Mean panting respiratory rate of different rams' conditions at different THI 1 - Argentina

\begin{tabular}{|c|c|c|c|c|c|c|c|c|c|c|c|c|c|c|}
\hline \multirow[b]{3}{*}{ THI 1} & \multirow[b]{3}{*}{$\mathbf{T}\left({ }^{\circ} \mathrm{C}\right)$} & \multirow[b]{3}{*}{ RH (\%) } & \multicolumn{6}{|c|}{ Standing } & \multicolumn{6}{|c|}{ Lying } \\
\hline & & & \multicolumn{3}{|c|}{ Unshorn } & \multicolumn{3}{|c|}{ Shorn } & \multicolumn{3}{|c|}{ Unshorn } & \multicolumn{3}{|c|}{ Shorn } \\
\hline & & & $\mathbf{N}$ & Mean RR & SD & $\mathbf{N}$ & Mean RR & SD & $\mathbf{N}$ & Mean RR & SD & $\mathbf{N}$ & Mean RR & SD \\
\hline 29 & 32 & 47 & 25 & 91.33 & 13.02 & 15 & 75.00 & 9.33 & - & - & - & - & - & - \\
\hline 30 & 33 & 46 & 27 & 104.81 & 19.88 & 36 & 96.67 & 22.30 & 1 & 110.00 & 0.00 & 1 & 90 & 0.00 \\
\hline 31 & 35 & 44 & 10 & 95.00 & 17.80 & 14 & 100.71 & 21.38 & 7 & 80.00 & 20.82 & - & - & - \\
\hline 32 & 36 & 44 & 52 & 119.23 & 16.67 & 32 & 102.81 & 22.03 & 7 & 75.71 & 7.87 & 3 & 80.00 & 17.32 \\
\hline 33 & 37 & 40 & 53 & 121.13 & 18.15 & 71 & 101.39 & 23.05 & 5 & 114.00 & 11.40 & 4 & 75.00 & 23.80 \\
\hline 34 & 39 & 40 & 104 & 130.96 & 14.38 & 142 & 115.24 & 21.78 & 17 & 97.06 & 23.92 & 6 & 80.00 & 14.14 \\
\hline 35 & 40 & 38 & 114 & 136.49 & 14.99 & 191 & 126.96 & 22.46 & 29 & 116.55 & 20.92 & 2 & 80.00 & 0.00 \\
\hline 36 & 41 & 38 & 148 & 143.38 & 16.27 & 206 & 131.46 & 0.25 & 16 & 121.88 & 18.34 & 12 & 87.50 & 29.58 \\
\hline 37 & 42 & 41 & 30 & 150.00 & 13.13 & 33 & 138.24 & 14.00 & - & - & - & - & - & - \\
\hline
\end{tabular}

Abbreviation: THI 1, Temperature-Humidity Index 1; T, Temperature; RH, relative humidity; N, number of respiratory rates; RR, respiratory rate; SD, standard deviation

\section{Modelling}

According to the Cumulative-Logit model:

$\operatorname{logit}\left[P\left(Y_{i t} \leq j / x\right]=\alpha_{j}+X^{\prime}{ }_{i t} \beta+Z^{\prime}{ }_{i t} b_{i}+e_{i t} \quad j_{=} 1, \ldots, J-1\right.$ as follows:

$\mathrm{RRp} \sim \mathrm{W} * \mathrm{P} * \mathrm{THI} 1+(1 \mid \mathrm{Ram})$

$\mathrm{RRp}=$ Panting respiratory rate, categorical variable (1-5)

$\mathrm{W}=$ Wool effect, unshorn/shorn

$\mathrm{P}=$ Ram position, standing/lying

THI $1=$ Temperature-Humidity Index 1

Ram $=$ subject

The results of the GLMM are presented in table 4. It is observed that the triple interaction between the $\mathrm{W}^{*} \mathrm{P}{ }^{*} \mathrm{THI}$ 1 effects is significant (Table 4.1). This indicates that the rams' $\mathrm{RRp}$ respond differently in shorn and unshorn rams, as well as in standing and lying at different THI 1. The categories used to group the RRp values were significant (Table 4.1). Since the variability of the subjects is different from zero, we concluded that there was variability due to the rams (standard deviation $=0.5583$ ). As a result of the likelihood test, by comparing the two models with and without the random effect, the model that considered the "Ram" effect significant justifies the use of a mixed model (Table 4.2).

Table 4 - Generalized linear mixed model results

Table 4.1- Estimation and threshold coefficients

\begin{tabular}{lcc}
\hline & Estimate & $\operatorname{Pr}(>|\mathbf{z}|)$ \\
\hline Wool & 0.6441 & 0.7304 \\
Position & 6.8490 & 0.1168 \\
THI 1 & 0.6382 & $<2 \mathrm{e}^{-16}$ \\
Wool * Position & -15.8208 & 0.0044 \\
Wool * THI 1 & 0.0218 & 0.6840 \\
\hline
\end{tabular}

\begin{tabular}{lcc}
\hline Position * THI 1 & -0.3065 & 0.0152 \\
Wool * Position * THI 1 & 0.4823 & 0.0029 \\
$\mathbf{1 | 2}$ & 14.0970 & \\
$\mathbf{2} \mid \mathbf{3}$ & 18.1520 & \\
$\mathbf{3} \mid \mathbf{4}$ & 21.2000 & \\
$\mathbf{4} \mid \mathbf{5}$ & 24.4130 \\
\hline
\end{tabular}

Table 4.2 - Likelihood test

\begin{tabular}{cccccccc}
\hline & $\begin{array}{c}\text { no. } \\
\text { par }\end{array}$ & AIC & logLik & LR.stat & df & $\operatorname{Pr}(>$ Chisq $)$ & \\
\hline Fixed & 11 & 2699.30 & -1338.60 & & & & \\
$\begin{array}{c}\text { Mixed } \\
\text { Ram }\end{array}$ & 12 & 2618.70 & -1297.40 & 82.57 & 1 & $<2.2 \mathrm{e}^{-16}$ & $* * *$ \\
\hline
\end{tabular}

Table 5 - Estimation coefficients of generalized linear mixed model

Table 5.1 - Unshorn and shorn rams

\begin{tabular}{lcccc}
\hline & \multicolumn{2}{c}{ Unshorn } & \multicolumn{2}{c}{ Shorn } \\
\cline { 2 - 5 } & Estimate & $\operatorname{Pr}(>|\mathrm{z}|)$ & Estimate & $\operatorname{Pr}(>|\mathrm{z}|)$ \\
\cline { 2 - 5 } Position & -12.8721 & 0.3480 & 6.2740 & 0.2000 \\
THI 1 & 0.7510 & $<2 \mathrm{e}^{-16}$ & 0.5838 & $<2 \mathrm{e}^{-16}$ \\
Position * THI 1 & 0.2759 & 0.4890 & -0.2801 & 0.0480 \\
\hline
\end{tabular}

Table 5.2 - Standing and lying rams

\begin{tabular}{lcccc}
\hline & \multicolumn{2}{c}{ Standing } & \multicolumn{2}{c}{ Lying } \\
\cline { 2 - 5 } & Estimate & $\operatorname{Pr}(>|\mathrm{z}|)$ & Estimate & $\operatorname{Pr}(>|\mathrm{z}|)$ \\
\cline { 2 - 5 } Wool & 0.4604 & 0.8050 & -22.7791 & 0.0283 \\
THI 1 & 0.6281 & $<2 \mathrm{e}^{-16}$ & 0.2802 & 0.2690 \\
Wool * THI 1 & 0.0257 & 0.6310 & 0.7307 & 0.0159 \\
\hline
\end{tabular}

Because the interpretation of the odds' ratio in a model with a triple interaction is quite difficult, four models were 
obtained, taking into account the conditions of rams: unshorn, shorn, standing and lying.

In table 5.1, we can see that, for the unshorn rams, the interaction $P$ * THI 1 was not significant ( $p=0.4890)$, but the main effect THI 1 was $\left(p=<2^{e-16}\right)$ indeed significant. Therefore, the RRp of
Us rams responded to different THI 1 values in the same way, whether standing or lying down (Figure 2.a). However, the interaction THI 1 for shorn rams was significant ( $p=0.0480)$, so we can say that the RRp of $S$ rams responded differently to the THI 1 values, whether they were standing or lying (Figure 2.b).

a

Unshorn

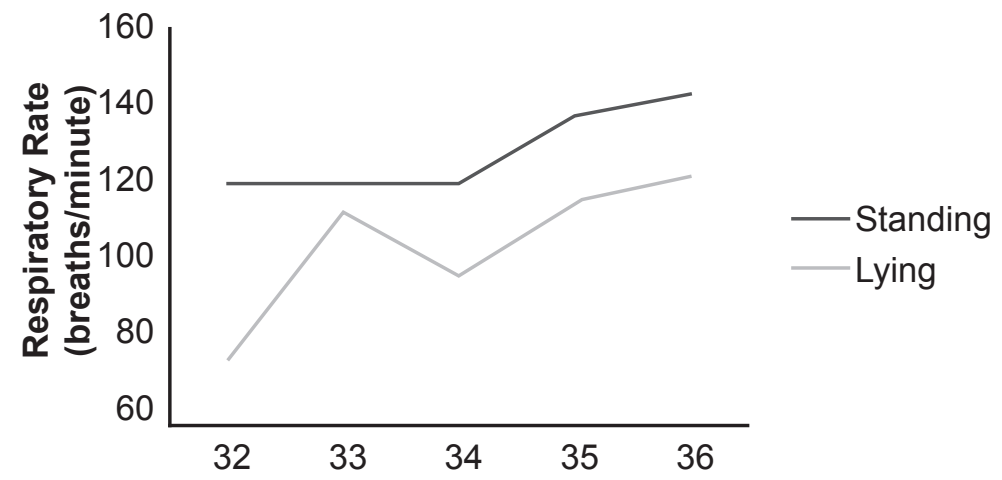

THI

b

Shorn

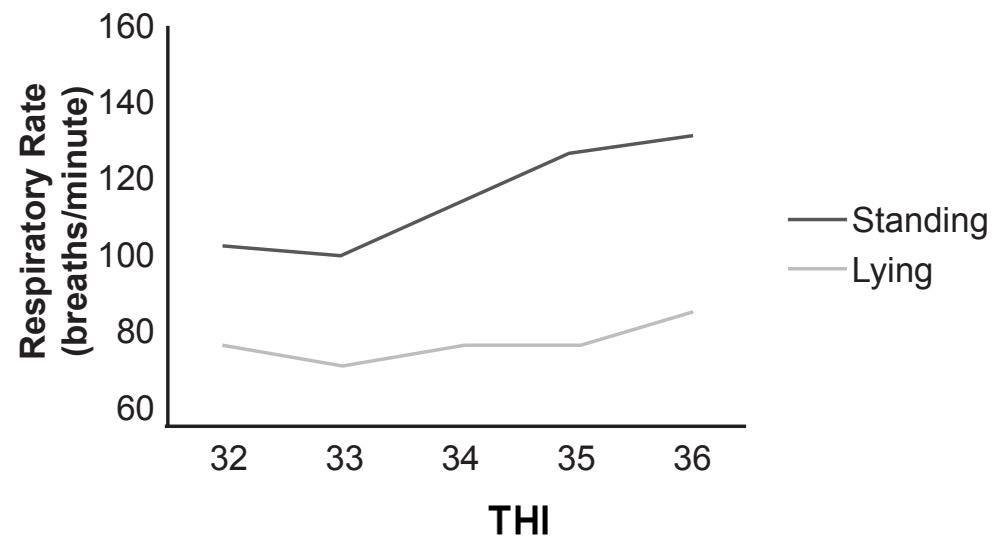

Figure 2 - Percentage of panting at different THI (32 to 36) in unshorn and shorn rams. a. Respiratory rate (breaths/minute) at different THI in unshorn rams. b. Respiratory rate (breaths/minute) at different THI in shorn rams

In table 5.2 we can see that for the standing rams, the interaction $\mathrm{W}$ * THI 1 was not significant $(\mathrm{p}=0.6310)$, but the main THI 1 effect was $\left(\mathrm{p}=<2^{\mathrm{e}-16}\right)$. Therefore, the RRp of Us and $\mathrm{S}$ rams responded in the same way to different
THI 1 values (Figure 3.a). However, the interaction $\mathrm{W}^{*}$ THI 1 for lying rams was significant ( $\mathrm{p}=0.0159)$, so we can say that lying Us and $S$ rams presented different RRp values in the different THI 1 values (Figure 3.b). 


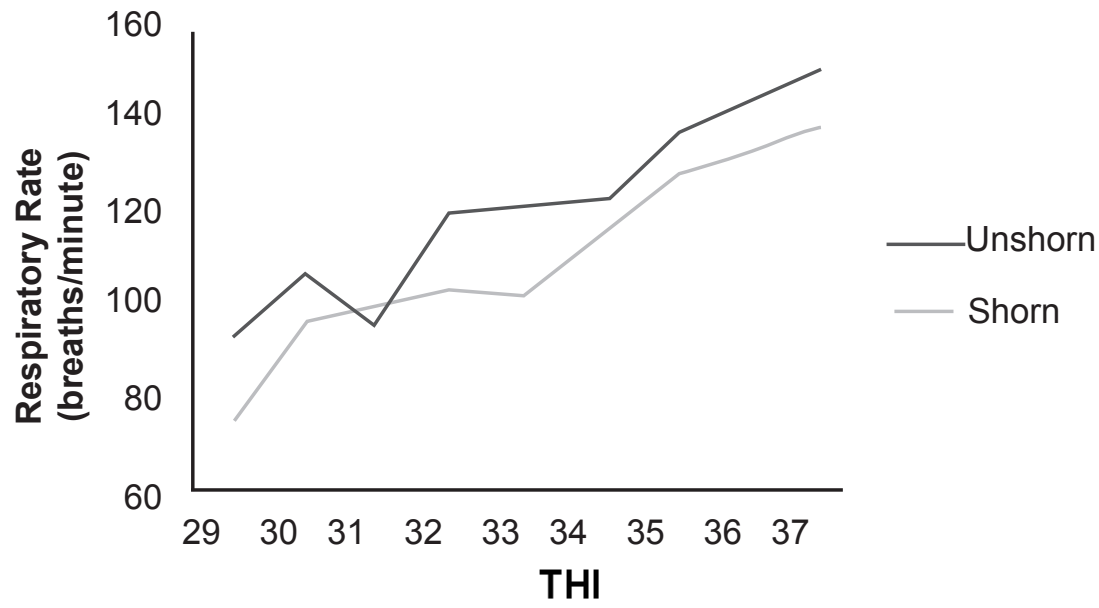

b Lying

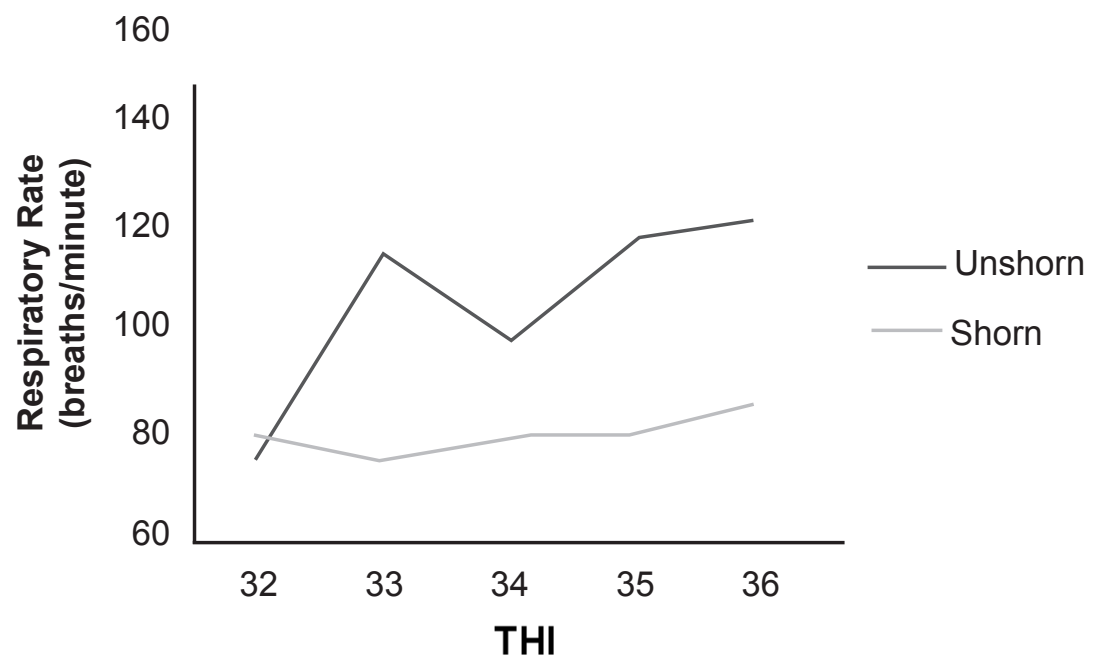

Figure 3 - Percentage of panting at different THI in standing and lying rams. a. Respiratory rate (breaths/minute) at different THI (29 to 37) in standing rams. b. Respiratory rate (breaths/minute) at different THI (32 to 36 ) in lying rams

\section{Discussion}

According to temperature and humidity conditions (temperature between 31.5 to $42^{\circ} \mathrm{C}$ and humidity between 32 to $48 \%$, THI 1 between 28.6 to 37.1 ) to which the rams were subjected for 40 hours over five days, the rams were under extreme severe heat stress inside the heat chamber (MARAI et al., 2009). An increase in RR of rams exposed to a hot environment was expected. At all times, it was observed that the rams inside the heat chamber were in the first phase of panting, which consisted of shallow movements that draw air backward and forwards on the moist surface of the naso-buccal region; occasionally the animal performs a deep breathing that responds to the need of gas exchange. However, the rams were never observed in the second phase of panting, which is characterized by deeper, slower respirations with the mouth open and tongue protruding (HALES; WEBSTER, 1967).

With regards to the comparative analysis of THI 1 and THI 2, low values were observed in the determination and correlation coefficients between RRp and THI. A plausible explanation for such a result may be that the RRp was explained by other factors (wool: unshorn/ shorn and position: standing/lying). Although the THI 1 (LPHSI) used in Egyptian Suffolk by Marai et al. (2009) showed higher values in the determination and correlation coefficients, the difference was too small, which is why we consider the THI from the National Research Council (1971) to be useful in order to measure the thermal stress in hot and dry climates, as Bohmanova et al. (2007) proposed 
when evaluating this index as indicator of milk production losses due to heat stress by comparing the cities of Athens (Georgia) and Phoenix (Arizona).

The five categories of panting employed in this research, i.e. the ones proposed by Silanikove (2000) and the two proposed in this paper (for RRp from 120 to $190 \mathrm{bpm}$ ), are useful to analyse the panting in rams under conditions of extreme severe heat stress.

In the case of unshorn rams, according to the model, the differences in RRp between different positions at different THI 1 values were not significant (Table 5.1; Figure 2). A plausible explanation is that the wool acted as an insulator and made the direct conductive heat exchange difficult between the ram and the air when it was standing and between the ram and the floor when it was lying down.

Shorn rams responded differently according to their position; when they were lying down their RRp was lower than when they were standing (Table 5.2; Figure 3). Plausible explanations are that when the rams are standing they are spending more muscle energy, therefore producing more heat in contrast to the resting position. Also the conductive heat exchange occurred more when the shorn ram was in contact with the floor, meaning that a shorter fleece only facilitated the heat loss when this surface was at a lower temperature than the surface of the ram.

According to the model, the differences observed in the RRp of standing rams at different THI 1 values were not significant (Table 5.2). This result coincides with Hofman and Riegle (1977) who conclude that in hot, dry heat without solar radiation, there was no difference between shorn and unshorn sheep in terms of respiratory frequency. A plausible explanation is that conductive heat transfer is only a minor source of heat gain when the animal is standing. This is because most heat transfer takes place in the air, and air is a poor thermal conductor (MOUNT, 1979). Direct conductive heat exchange occurs if an animal is in contact with solid surfaces at a different temperature to the surface of the animal. Furthermore, when the animal lies down heat production from muscle activity is lower, and the conductive heat transfer is greater than when standing, but this depends on the thermal conductance of the substrate, the temperature gradient and the magnitude of the area of contact relative to the total surface area of the animal (ROBERTSHAW, 1985). As a result of this work, the above-mentioned result was observed in the shorn lying rams (Table 5.2): they had the lowest RRp because heat production from muscle activity was lower and heat loss was more effective.

In conclusion, Australian Merino rams from Northern Patagonia are heat tolerant to an environment between 31.5 to $42^{\circ} \mathrm{C}$ and 32 to $48 \%$ humidity for 40 hours over five days. The rams were in the first phase of panting, and the rectal temperatures registered daily when leaving the heat chamber confirmed that the regulation of body temperature in the rams was successful because they attested normal rectal temperature in sheep when leaving the heat chamber. By counting flank movements, respiration rate was registered in breaths per minute in an interval of time, and panting was distinguished from deep breath (gas exchange). From the modelling of $R R p$, as a response variable of the rams' conditions at different environmental conditions (THI), it is possible to conclude that there were not significant differences in the RRp values between unshorn (standing or lying) and standing (unshorn or shorn) sheep, but there were significant differences in shorn and lying rams. The RRp values were lower in the shorn, lying rams because heat production from muscle activity was lower and heat conduction between the ram and floor is facilitated when the fleece is short (at least 0.7 inches long), while in unshorn rams the long fleece acts as an insulator, both in contact with the air and with the floor and does not facilitate the processes of heat loss by conduction. Although the LPHSI's THI was adjusted to improve the analysis of the RR more than the National Research Council's THI, and given that the differences in the determination and correlation coefficients were too low because of the interaction of other effects on RRp (shearing and position), both THIs are recommended for the analysis of physiological variables in ovines in hot and arid climates.

\section{Acknowledgements}

This work was supported by Grant 04 / A 109 and 04/ A 126 from the Universidad Nacional del Comahue and Consejo Interuniversitario Nacional, Argentina. 


\section{References}

ALHIDARY, I. A.; SHINI, S.; AL JASSIM, R. A. M.; GAUGHAN, J. B. Physiological responses of Australian Merino wethers exposed to high heat load. Journal of Animal Science, v. 90, n. 1, p. 212-220, 2012. doi: 10.2527/ jas.2011-3972.

ARAÚZ, E. E. Importancia del microambiente para el desempeño fisiológico y efectos negativos del estrés calórico sobre la capacidad fisiológica y de producción en los caprinos y ovinos. Engormix, 2009. Available from: $<$ https://www.engormix.com/MA-ovinos/articulos/ importancia-microambiente-desempeno-fisiologicot2736/165-p0.htmacces>. Viewed: 22 Feb. 2017.

ARIAS, R. A.; MADER, T. L.; ESCOBAR, P. C. Climatic factors affecting cattle performance in dairy and beef farms. Archivos de Medicina Veterinaria, v. 40, n. 1, p. 7-22, 2008. doi: 10.4067/S0301-732X2008000100002.

BEATTY, D. T.; BARNES, A.; FLEMING, P. A.; TAYLOR, E.; MALONEY, S. K. The effect of fleece on core and rumen temperature in sheep. Journal of Thermal Biology, v. 33, n. 8, p. 437-443, 2008. doi: 10.1016/j.jtherbio.2008.07.002.

BIANCA, W. Reviews of the progress of dairy science. Journal of Dairy Research, v. 32, n. 3, p. 291-345, 1965. doi: $10.1017 /$ S0022029900018665.

BOHMANOVA, J.; MISZTAL, I.; COLE, J. B. TemperatureHumidity Indices as indicators of milk production losses due to heat stress. Journal of Dairy Science, v. 90, n. 4, p. 1947-1956, 2007. doi: 10.3168/jds.2006-513.

BROWN-BRANDL, T. M.; EIGENBERG, R. A.; NIENABER, J. A. Heat stress risk factors of feedlot heifers. Livestock Science, v. 105, n. 1-3, p. 57-68, 2006. doi: 10.1016/j.livsci.2006.04.025.

BROWN-BRANDL, T.M.;EIGENBERG, R.A.; NIENABER, J. A.; LEROY HAHN, G. Dynamic response indicators of heat stress in shaded and non-shaded feedlot cattle, part 1: analyses of indicators. Biosystems Engineering, v. 90, n. 4, p. 451-462, 2005. doi: 10.1016/j.biosystemseng.2004.12.006.
BRYANT, J. R.; MATTHEWS, L. R.; DAVYS, J. Development and application of a thermal stress model. In: AUSTRALASIAN DAIRY SCIENCE SYMPOSIUM, 4., 2010, Christchurch. Proceedings... Christchurch: Caxton Press, 2010. p. 360-364.

CAULFIELD, M. P.; CAMBRIDGE, H.; FOSTER, S. F.; MCGREEVY, P. D. Heat stress: a major contributor to poor animal welfare associates with long-haul live export voyages. The Veterinary Journal, v. 199, n. 2, p. 223-228, 2014. doi: 10.1016/j.tvjl.2013.09.018.

CURTIS, S. E. Environmental management in animal agriculture. Ames: Iowa State University Press, 1983. 409 p.

DUTT, R. H.; HAMM, P. T. Effect of exposure to high environmental temperature and shearing on semen production of rams in winter. Journal of Animal Science, v. 16, n. 2, p. 328-334, 1957. doi: 10.2527/jas1957.162328x.

HAFEZ, E. S. E. Reproduction in farm animals. 5. ed. Philadelphia: LEA \& Febiger, 1987. 649 p.

HALES, J. R. S.; BROWN, G. D. Net energetic and thermoregulatory efficiency during panting in the sheep. Comparative Biochemistry and Physiology Part A: Physiology, v. 49, n. 3, p. 413-422, 1974. doi: 10.1016/03009629(74)90557-X.

HALES, J. R. S.; WEBSTER, M. E. D. The Journal of Physiology, v. 190, n. 2, p. 241-260, 1967. doi: 10.1113/ jphysiol.1967.sp008205.

HOFMAN, W. F.; RIEGLE, G. D. Thermo respiratory responses of shorn and unshorn sheep to mild heat stress. Respiration Physiology, v. 30, n. 3, p. 327-338, 1977. doi: 10.1016/0034-5687(77)90039-1.

KARAMAN, S.; AKSOY, Y.; DUMAN, M.; ULUTAS, $Z$. Impacts of climate parameters on physiological characteristics of Karayaka sheep. Journal of the Faculty of Veterinary Medicine Kafkas University, v. 19, n. 3, p. 499-504, 2013. 
LOBLEY, G. E. Energy metabolism reactions in ruminant muscle: responses to age, nutrition and hormonal status. Reproduction Nutrition Development, v. 30, n. 1, p. 13-34, 1990.

LPHSI. Livestock and poultry heat stress indices agriculture engineering technology guide. Clemson: Clemson University, 1990.

MARAI, I. F. M.; AYYAT, M. S.; ABD EL-MONEM, U. $M$. Growth performance and reproductive traits at first parity of New Zealand White female rabbits as affected by heat stress and its alleviation, under Egyptian conditions. Tropical Animal Health and Production, v. 33, n. 6, p. 451-462, 2001. doi: 10.1023/A:1012772311177.

MARAI, I. F. M.; EL-DARAWANY, A. A.; ABOUFANDOUD, E. I.; ABDEL-HAFEZ, M. A. M. Reproductive and physiological traits of Egyptian Suffolk rams as affected by selenium dietary supplementation during the subtropical environment of Egypt. Livestock Research for Rural Development, v. 21, n. 10, article 157, p. 157, 2009.

MCCARTHY, M. Pilot monitoring of shipboard environmental conditions and animal performance. North Sydney: Meat \& Livestock Australia, 2005. 30 p.

MEAT \& LIVESTOCK AUSTRALIA. Heat load in feedlot cattle. Sydney: MLA, 2001. 34 p.

MONTY JUNIOR, D. E.; KELLEY, L. M.; RICE, W. R. Acclimatization of St. Croix, Karakul and Rambouillet sheep to intense and dry summer heat. Small Ruminant Research, v. 4, n. 4, p. 379-392, 1991. doi: 10.1016/09214488(91)90083-3.

MOUNT, L. E. Adaptation to thermal environment: man and his productive animals. London: Edward Arnold Publishers, 1979. 333 p.
NATIONAL RESEARCH COUNCIL. A guide to environmental research on animals. Washington: National Academy of Sciences, 1971.

R CORE TEAM. R: a language and environment for statistical computing, R Foundation for Statistical Computing. Vienna: $\mathrm{R}$ Foundation for Statistical Computing, 2015.

ROBERTSHAW, D. Heat loss in cattle. In: YOUSEF, M. $\mathrm{K}$. Stress physiology in livestock: basic principles. Boca Raton: CRC Press, 1985. v. 1. p. 55-67.

SCHMIDT-NIELSEN, K. Animal physiology: adaptation and environment. 5. ed. Cambridge: Cambridge University Press, 1997. 607 p.

SILANIKOVE, N. Effects of heat stress on the welfare of extensively managed domestic rumiants. Livestock Production Science, v. 67, n. 1-2, p. 1-18, 2000. doi: 10.1016/ S0301-6226(00)00162-7.

SOLYMOSI, N.; TORMA, C.; KERN, A.; MARÓTIAGÓTS, A.; BARCZA, Z; KÖNYVES, L.; BERKE, O; REICZIGEL, J. Changing climate in Hungary and trends in the annual number of heat stress days. International Journal of Biometeorology, v. 54, n. 4, p. 423-431, 2010. doi: 10.1007/s00484-009-0293-5.

STOCKMAN, C. A. The physiological and behavioural responses of sheep exposed to heat load within intensive sheep industries. 2006. $287 \mathrm{f}$. Thesis (PhD in Veterinary and Biomedical Sciences) - Murdoch University, Western Australia, 2006.

THWAITES, C. J. Physiological responses and productivity in sheep. In: YOUSEF, M. K. Stress physiology in livestock: basic principles. Boca Raton: CRC Press, 1985. v. 1. p. 47-55. 